\title{
Adaptation of proteases and carbohydrases of saprophytic, phytopathogenic and entomopathogenic fungi to the requirements of their ecological niches
}

\author{
Raymond J. St Leger, Lokesh Joshi and Donald W. Roberts \\ Author for correspondence: Raymond J. St Leger. Tel: + 1607254 1370. Fax: +1 6072541242. \\ e-mail:rs50@cornell.edu
}

The Boyce Thompson Institute at Cornell University, Tower Road, Ithaca, NY 14853, USA
The abilities of isolates of saprophytes (Neurospora crassa, Aspergillus nidulans), an opportunistic human pathogen (Aspergillus fumigatus), an opportunistic insect pathogen (Aspergillus flavus), plant pathogens (Verticillium albo-atrum, Verticillium dahliae, Nectria haematococca), a mushroom pathogen (Verticillium fungicola) and entomopathogens (Verticillium lecanii, Beauveria bassiana, Metarhizium anisopliae) to utilize plant cell walls and insect cuticle components in different nutrient media were compared. The pathogens showed enzymic adaptation to the polymers present in the integuments of their particular hosts. Thus, the plant pathogens produced high levels of enzymes capable of degrading pectic polysaccharides, cellulose and xylan, as well as a cutinase substrate, but secreted little or no chitinase and showed no proteolytic activity against elastin and mucin. The entomopathogens and $\boldsymbol{V}$. fungicola degraded a broad spectrum of proteins (including elastin and mucin) but, except for chitinase, cellulase ( $V$. lecanii and $V$. fungicola only) and cutinase (B. bassiana only), produced very low levels of polysaccharidases. The saprophytes ( $\mathrm{Neu}$. crassa and $\mathrm{A}$. nidulans) and the opportunistic pathogens (A. fumigatus and A. flavus) produced the broadest spectrum of protein and polysaccharide degrading enzymes, indicative of their less specialized nutritional status. $\boldsymbol{V}$. lecanii and $\boldsymbol{V}$. albo-atrum were compared in more detail to identify factors that distinguish plant and insect pathogens. V. albo-atrum, but not $V$. lecanii, grew well on different plant cell wall components. The major class of proteases produced in different media by isolates of $V$. albo-atrum and $V$. dahliae were broad spectrum basic (pl $>10)$ trypsins which degrade Z-AA-AA-Arg-NA substrates (Z, benzoyl; AA, various amino acids; NA, nitroanilide), hide protein azure and insect (Manduca sexta) cuticles. Analogous peptidases were produced by isolates of $\boldsymbol{V}$. lecanii and V. fungicola but they were specific for Z-Phe-Val-Arg-NA. V. albo-atrum and V. dahliae also produced low levels of neutral (pl ca 7) and basic (pl ca 9.5) subtilisin-like proteases active against a chymotrypsin substrate (Succinyl-Ala - $^{-}$ Pro-Phe-NA) and insect cuticle. In contrast, subtilisins comprised the major protease component secreted by $V$. lecanii and $V$. fungicola. Both $V$. lecanii and $V$. albo-atrum produced the highest levels of subtilisin and trypsin-like activities during growth on collagen or insect cuticle. Results are discussed in terms of the adaptation of fungi to the requirements of their ecological niches.

Keywords: entomopathogenic fungi, phytopathogenic fungi, saprophytic fungi, protease production, carbohydrase production

Abbreviations: AFC, 7-amino-4-trifluoromethyl coumarin; EOMs, enzyme overlay membranes; NA, nitroanilide; PG, polygalacturonase; Pr1, subtilisin-like protease; $\mathrm{Pr}$, trypsin-like protease; Suc, succinyl; Z, benzoyl. 


\section{INTRODUCTION}

Fungal pathogens have been recorded for virtually all groups of multicellular organisms. All classes of Eumycotina contain at least a few plant pathogens. Likewise, at least 90 genera and more than 700 species of fungi have been identified as insect pathogens (Roberts \& Humber, 1981). For most fungal diseases, the genes and their products in both host and pathogen that limit host range and determine resistance or susceptibility are poorly understood. However, for a few model systems, molecular genetic approaches are beginning to identify microbial and host products that influence the progression of infection (Bowyer et al., 1995; Hensel \& Holden, 1996; Knogge, 1996; Oliver \& Osburn, 1995; Schafer, 1994).

The ability to infect insects must have evolved independently many times since pathogenic fungi are found in several divergent fungal groups. The huge variety of insects has given fungi countless opportunities to exploit them; the antiquity and subsequently extended co-evolution of such interrelationships being reflected in their present ubiquity and often high degree of sophistication (Cooke \& Whipps, 1993). Obviously, given the many routes by which fungi have achieved their success as entomopathogens, different evolutionary pressures may have operated in taxonomically diverse groups. Nevertheless, to determine how pathogenicity evolved it might be useful to ask in what aspects does an entomopathogen differ from a saprophyte or plant pathogen. Fungi may have emerged onto the land as endophytes of plants (Lewis, 1987). Insect-pathogenic fungi could have evolved from these or from plantpathogenic fungi derived from these via adaptations in extracellular hydrolytic enzymes so as to accommodate hydrolysis of proteinaceous insect cuticles (St Leger \& Bidochka, 1996). Plant-pathogenic fungi produce a complement of extracellular enzymes that degrade carbohydrate plant tissues (Walton, 1994). The structure of these tissues is analogous to those found in insect cuticle, i.e. both are composite structures containing a fibrous material (chitin or cellulose) embedded in a matrix material (protein or pectic substances and hemicelluloses) (Carpita \& Gibeaut, 1993; Charnley, 1984) and many of the plant pathogens possess structural and behavioural adaptations which are very similar to the entomopathogens, e.g. they produce an ordered sequence of infection structures, including appressoria. These observations strongly suggest that some of the underlying mechanisms of fungal pathogenesis may be similar in insects and plants. Since a vast majority of insects are herbivores, the opportunity for association of a plant-pathogenic fungus on an insect would be high. With the exception of the Entornophthorales (Zygomycetes), many fungi that infect plants and invertebrates fall within the same taxonomic groups. Species within the genus Verticillium include plant, human, nematode and insect pathogens (Segers et al., 1994; Schreiter et al., 1994; Amici et al., 1994; Cooper \& Wood, 1975) and may represent a divergent genus that has evolved pathogenic specialization for various life forms. Aside from Verticillium spp. there is little overlap between plant and insect pathogens at the genus level in fungi (even those which, like Verticillium, are based on morphology of asexual stages) and virtually none at the species level. It follows that some of the characteristics needed by fungi to successfully establish disease in plants must be fundamentally different in some way from those needed to infect insects. These differences, when clearly delineated, will indicate probable key virulence characters for pathogens of the two host groups.

The present study comprises a comparative analysis of depolymerases produced by saprophytes and opportunists (Aspergillus spp. and Neurospora crassa) and pathogens of plants (Nectria haematococca, Verticillium albo-atrum, Verticillium dabliae), insects (Verticillium lecanii, Beauveria bassiana, Metarhizium anisopliae) and fungi (Verticillium fungicola).

\section{METHODS}

Organisms and growth. A. nidulans strain A4 and Neu. crassa strain 2489 were obtained from the Fungal Genetic Stock Center in the University of Kansas Medical Center, KS, USA. A. fumigatus strain 16424 was obtained from the American Type Culture Collection, Rockville, MD, USA. It was isolated from a human patient with aspergillosis. The entomopathogens A. flavus strain 3144 (host: gypsy moth, Lymantria dispar), B. bassiana strains 252 (host: Colorado potato beetle, Leptinotarsa decemlineata) and 1630 (host: Calliphora spp.), M. anisopliae strains 1080 (host: Heliothis zea) and 2575 (host: pecan weevil, Curculio caryae), V. lecanii strains 313 (single spore isolate of Vertelac), 1335 (host: Malachius bipustulatus) and 3709 (host: Homoptera, Aleyrodidae) and $V$. fungicola strain 2065 (host: egg mass, Lymantria dispar) were obtained from the USDA Entomopathogenic Fungus Collection, Ithaca, NY, USA. The mushroom pathogen $V$. fungicola strain VAMH 895 (cause of brown spot disease in mushrooms) was obtained from the University of Alberta Microfungus Collection and Herbarium, Canada. The plant pathogens $V$. albo-atrum strains 13-1, 26-1, 90-1 and 98-1 (host: alfalfa, Medicago sativa), V. dabliae (host: maple) were obtained from the teaching collection of the Department of Plant Pathology, Cornell University, Ithaca, NY, USA. Nec. haematococca (Fusarium solanii) strain T8 (host: pea plant) was obtained from Dr Olen Yoder, Department of Plant Pathology Cornell University, Ithaca, NY, USA.

Enzyme production on solid media. Enzyme activity was determined by the ability to produce zones of clearing in $1.2 \%$ $(\mathrm{w} / \mathrm{v})$ agar media containing suitable substrates. Cellulase and xylanase activities were measured using minimal medium (MM) $\left(0.3 \% \mathrm{NaNO}_{3}, 0.1 \% \mathrm{KH}_{2} \mathrm{PO}_{4}, 0.05 \% \mathrm{MgSO}_{4}, \mathrm{pH} 6\right)$ supplemented with $0.1 \%$ yeast extract and $0.5 \% \mathrm{CM}$-cellulose (medium viscosity) or birchwood xylan. For both media, clearing zones were visualized by staining with $1 \mathrm{mg}$ Congo red $\mathrm{ml}^{-1}$ for $15 \mathrm{~min}$, then destaining with $1 \mathrm{M} \mathrm{NaCl}$ (Teather $\&$ Wood, 1982). Polygalacturonase (PG) and pectin lyase were detected using the pectic screening media devised by Durrands \& Cooper (1988) to study pectinase mutants of V. albo-atrum. PG detection medium contained non-methylated polygalacturonan (sodium polypectate) buffered at $\mathrm{pH} 5.0(0.05 \mathrm{M}$ sodium citrate) and was calcium free. In contrast, pectin lyase medium contained polymethylgalacturonan (pectin) buffered 
at $\mathrm{pH} 8 \cdot 0(0.05 \mathrm{M}$ HEPES) and contained calcium-rich agar. PG and PL activity were detected on these media by addition of $1 \%(\mathrm{w} / \mathrm{v})$ cetyltrimethylammonium bromide which precipitated undegraded substrate. Chitinase activity was detected using MM supplemented with $0.05 \%$ yeast extract and $0.2 \%$ (dry wt) colloidal chitin adjusted to $\mathrm{pH} 5 \cdot 5$. Plates were prepared in the manner described by Hankin \& Anagnostakis (1975) with an underlay of $1.5 \%$ agar and a $3 \mathrm{~mm}$ overlay of the chitin medium. Cutinase activity was detected using the polycaprolactone screening medium devised by Murphy et al. (1996). This contained MM (pH 6.0) supplemented with $0.1 \%$ yeast extract and $0.5 \%$ polycaprolactone, which formed a cloudy suspension so that clearing zones produced by secreted fungal enzymes could be measured directly.

Proteolytic activity was detected using MM solution (adjusted to $\mathrm{pH} 7$ using $\mathrm{NaOH}$ ) supplemented with $0 \cdot 1 \%$ yeast extract and $0 \cdot 1 \%$ elastin, $0 \cdot 3 \%$ porcine stomach mucin or $0 \cdot 1 \%$ hide protein azure. The test medium was prepared at double strength without agar and autoclaved separately. The components were cooled to about $50^{\circ} \mathrm{C}$ before mixing.

Spores of each strain were point-inoculated onto agar surfaces and incubated at $25^{\circ} \mathrm{C}$ for up to $7 \mathrm{~d}$ or until mycelial colonies reached $30 \mathrm{~mm}$ in diameter. Neu. crassa produced a thin netlike mycelium on the surface of the agar and a small diameter colony within the agar which produced a measurable halo of substrate degradation.

Preparation and analysis of culture filtrate. Cultures were inoculated with spores taken from 7-to 12-d-old agar plates or with standardized mycelial inocula $(0.5 \mathrm{~g}$ wet wt per $10 \mathrm{ml})$ from $48 \mathrm{~h}$ Sabouraud dextrose cultures. The $250 \mathrm{ml}$ conical flasks were incubated with shaking $(100$ r.p.m. $)$ at $25^{\circ} \mathrm{C}$ for up to $4 \mathrm{~d}$ in 20,50 or $100 \mathrm{ml}$ basal medium (containing, $\mathrm{1}^{-1}: 1 \mathrm{~g}$ $\mathrm{KH}_{2} \mathrm{PO}_{4}, 0.5 \mathrm{~g} \mathrm{MgSO}_{4}, 0.7 \mathrm{mg} \quad \mathrm{Na}_{2} \mathrm{~B}_{4} \mathrm{O}_{7} .10 \mathrm{H}_{2} \mathrm{O}, 0.5 \mathrm{mg}$ $\left(\mathrm{NH}_{4}\right)_{6} \mathrm{Mo}_{7} \mathrm{O}_{24} \cdot 4 \mathrm{H}_{2} \mathrm{O}, 10 \cdot 0 \mathrm{mg} \quad \mathrm{Fe}_{2}\left(\mathrm{SO}_{4}\right)_{3} .6 \mathrm{H}_{2} \mathrm{O}, 0 \cdot 3 \mathrm{mg}$ $\mathrm{ZnSO}_{4} .7 \mathrm{H}_{2} \mathrm{O}$, adjusted to $\mathrm{pH} 6.0$ with $\mathrm{NaOH}$ ) supplemented with a carbon source at $0.5 \%$. Cultures were filtered through Whatman No. 1 filter paper and then through a $0.2 \mu \mathrm{m}$ pore Millipore filter unit before being used for enzyme assays.

Electrophoresis. Analytical IEF on ultrathin polyacrylamide gels was performed in an IEF cell (Bio-Rad) using $1 \%$ ampholytes (Bio-Lyte 3/10; Bio-Rad) as previously described (St Leger et al., 1996a). For gelatin SDS-PAGE, electrophoresis was done in $11 \%(\mathrm{w} / \mathrm{v})$ polyacrylamide gels containing $0.2 \%$ copolymerized gelatin (Lockwood et al., 1987). After electrophoresis, the gels were incubated for $60 \mathrm{~min}\left(35^{\circ} \mathrm{C}\right)$ in renaturation buffer $[0.05 \mathrm{M}$ Tris, $\mathrm{pH} 8$, containing $2.5 \%(\mathrm{v} / \mathrm{v})$ Triton X-100; St Leger et al., 1996a]. Protease activity against gelatin was detected by staining residual gelatin with Coomassie blue G-250. The molecular masses of the proteins were determined from a graph of log molecular mass versus migration distance of standard proteins (Bio-Rad).

To characterize protease isoforms, gels were overlaid with enzyme overlay membranes (EOMs) (St Leger et al., 1994). These were nitrocellulose membranes previously impregnated with fluorogenic substrates Suc-Ala $a_{2}$-Pro-Phe-AFC, Z-ValLeu-Arg-AFC and Z-Gly-Gly-Arg-AFC (Enzyme Systems Products) using procedures described by Smith (1984) (Suc, succinyl; AFC, 7-amino-4-trifluoromethyl coumarin; Z, benzoyl). Gels were incubated at $37^{\circ} \mathrm{C}$ and the appearance of fluorescent bands monitored by an ultraviolet lamp. The contact side of the membrane was visualized and photographed on thermal paper using an EagleEye II image capture system (Stratagene). The photographs were scanned using a flatbed scanner and Adobe Photoshop.
Preparation of plant cell walls and insect cuticle substrates. Clean samples of cuticle from fifth instar Manduca sexta larvae were prepared as described previously (St Leger et al., 1987a).

Cell walls were prepared from the stems of 8 -week-old alfalfa (M. sativa) seedlings by stripping off the leaves and extracting the comminuted stems with organic solvents (York et al., 1985).

Enzyme assays. Protease activity versus $M$. sexta cuticle, cuticle proteins, hide protein azure, subtilisin-like protease (Pr1) activity (versus Suc-Ala ${ }_{2}$-Pro-Phe-NA) and trypsin-like protease ( $\mathrm{Pr} 2$ ) activity (versus Z-Phe-Val-Arg-NA) were determined as described previously for $V$. lecanii and other entomopathogens (St Leger et al., 1987b, c) (NA, nitroanilide).

Polysaccharidase activities were assayed according to Riou et al. (1991) using the pH optima reported by Cooper \& Wood (1975) for enzymes from V. albo-atrum. Liberated reducing sugars were estimated with dinitrosalicylic reagent (Miller, 1959) using D-glucose as standard. Assays were repeated at $\mathrm{pH} \mathrm{4,6}$ and 8 in cultures containing no detectable activity at the reported $\mathrm{pH}$ optima.

Assays were performed in duplicate. All results are representative of at least two similar experiments using different enzyme preparations.

Materials. Reagents were procured as follows: Suc-Ala $\mathrm{A}_{2}-\mathrm{Pro}-$ Phe- $\mathrm{CH}_{2} \mathrm{Cl}$ and EOM components were from Enzyme Systems Products; polycaprolactone LPS-60 HP was from Union Carbide Chemicals and Plastics Company. Other enzyme substrates (including the polysaccharides) and inhibitors were from Sigma.

\section{RESULTS}

\section{Plate clearing assays}

Table 1 shows that saprophytes (A. nidulans, Neu. crassa) and opportunistic pathogens (A. fumigatus and A. flavus) secrete activities against a broad spectrum of protein and carbohydrate substrates. In contrast, we observed consistent patterns for the occurrence of extracellular enzymes distinguishing plant pathogens from insect pathogens. Plant pathogens were all able to degrade pectic substances, cellulose and xylan, as well as the cutinase substrate. By contrast, $V$. fungicola and the entomopathogens did not produce clearing zones in xylan or pectic substances, indicating that if xylanase, pectinases or PGs are secreted, they were at a level below the sensitivity of the assay. Isolates of M. anisopliae and B. bassiana did not produce detectable levels of cellulase. However, large clearing zones in cellulose medium formed around all strains of Verticillium spp., irrespective of their host. B. bassiana also produced clearing zones in polycaprolactone, but this plastic may also be a substrate of some non-cutinase esterases (Murphy et al., 1996).

All strains degraded hide protein azure, but only $\mathrm{Neu}$. crassa, Aspergillus spp., V. fungicola and the entomopathogens secreted proteases capable of degrading elastin or mucin. Likewise, none of the plant pathogens produced detectable levels of secreted chitinase. 
Table 1. Enzyme production by different species of fungi

Plates were point-inoculated and incubated for up to $7 \mathrm{~d}$ or until mycelia reached $30 \mathrm{~mm}$ in diameter. Enzyme activities were calculated as an index of the total diameter of the colony plus the clear zone around it divided by the diameter of the colony. When the value is $>1.0$ it indicates that the isolate is releasing the enzyme into the medium. When the value is $<1 \cdot 0$ it indicates partial clearing of the substrate under the colony. TR, partial clearing was observed under the centre of mature $(>7-\mathrm{d}$-old) cultures $>50$ mm in diameter.

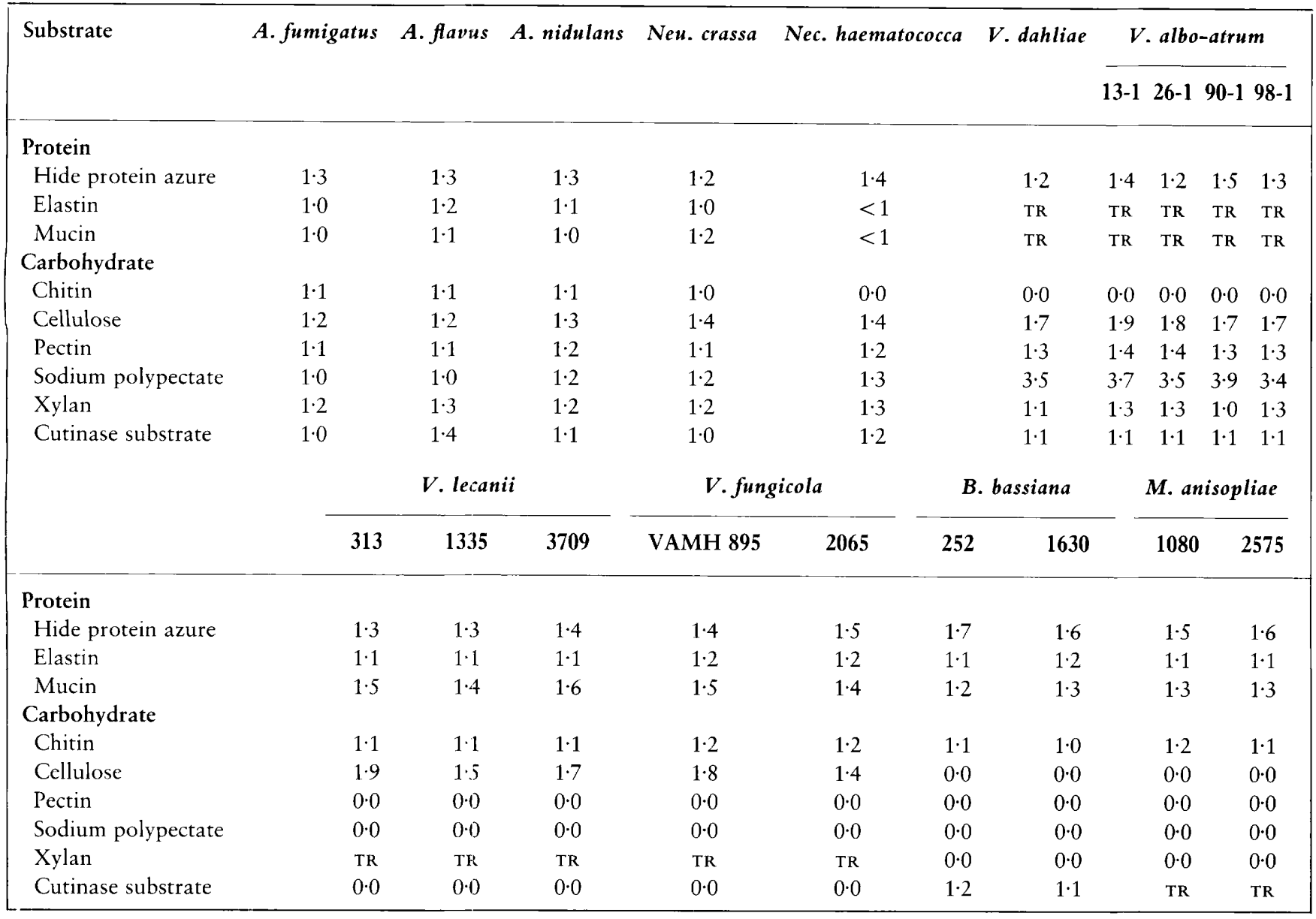

\section{Effect of the carbohydrate growth substrate on polysaccharidase activities}

The ability of V. lecanii isolate 313 and $V$. albo-atrum isolate 13-1 to metabolize the cell wall components of plants was evaluated in liquid cultures (Tables 2 and 3). As expected from studies by Cooper \& Wood (1975), V. albo-atrum was able to utilize pectic substances, cellulose and xylan as sole carbon sources and to secrete enzymes that convert cellulosic, hemicellulosic and pectic polysaccharides to assimilable simple sugars. Maximal activities were generally obtained in cultures grown on the appropriate structure-related polysaccharide (Table 2). By contrast, we observed only marginal growth of $V$. lecanii on individual carbohydrates with little or no activities against polysaccharides when assayed at the $\mathrm{pH}$ optima of enzymes from V. albo-atrum (Cooper \& Wood, 1975) and at $\mathrm{pH} \mathrm{4,6}$ or 8 . The biomasses produced in these cultures were much lower than those obtained on glucose media
(Table 3). In comparison to enzyme production on single carbohydrates, both $V$. lecanii and V. albo-atrum showed greatly enhanced enzyme production on alfalfa cell walls. Pectinase activities produced by $V$. alboatrum against pectin and polygalacturonic acid were, respectively 4 and 44 times higher in cell wall media than in media containing only polygalacturonic acid or pectin. Cell walls were the only carbohydrate substrate that induced production of a polysaccharidase (PG) by $V$. lecanii. However, this enzyme was also produced in insect cuticle media, indicating that increases in enzyme activity can be unrelated to the carbon source.

\section{Identification of Verticillium spp. proteinases}

Seven bands with a pI range $6 \cdot 8-9 \cdot 6$ could be distinguished on IEF gels when protease activity in collagen-grown cultures of $V$. lecanii strain 1335 was detected with the Pr1 subtilisin substrate Suc-Ala ${ }_{2}$-Pro- 
Table 2. Protease and polysaccharidase activities of extracellular preparations from $V$. albo-atrum strain 13-1 grown on a range of carbon sources for $4 \mathrm{~d}$

Cultures $(50 \mathrm{ml})$ were inoculated with $2 \times 10^{6}$ spores.

\begin{tabular}{|c|c|c|c|c|c|c|c|}
\hline \multirow{2}{*}{$\begin{array}{l}\text { Carbohydrate } \\
\text { growth substrate }\end{array}$} & \multicolumn{4}{|c|}{ Sugar released $\left(\mu \mathrm{g} \mathrm{ml}^{-1} \mathrm{~h}^{-1}\right)^{*}$} & \multicolumn{2}{|c|}{$p \mathrm{NA}$ released $\left(\mathrm{nmol} \mathrm{ml} \mathbf{l}^{-1} \mathrm{~min}^{-1}\right)^{*}$} & \multirow{2}{*}{$\begin{array}{c}\text { Biomass } \\
(\mathrm{mg} \text { dry } w \mathrm{t}) \dagger\end{array}$} \\
\hline & Pectin & PGA $\neq$ & Xylan & CMCS & $\begin{array}{c}\text { Suc-Ala }- \\
\text { Pro-Phe-NA }\end{array}$ & $\begin{array}{l}\text { Z-Phe-Val- } \\
\text { Arg-NA }\end{array}$ & \\
\hline Alfalfa cell walls & $473 \pm 54$ & $1549 \pm 126$ & $110 \pm 21$ & $34 \pm 8$ & $10 \pm 3$ & $44 \pm 11$ & $\mathrm{NM}$ \\
\hline M. sexta cuticle & 10 & $\overline{43}$ & $\overline{0}$ & $\overline{0}$ & $14 \pm 3$ & $94 \pm 11$ & NM \\
\hline Pectin & $86 \pm 17$ & $35 \pm 6$ & $4 \pm 1$ & $3 \pm 0$ & 0 & $3 \pm 0$ & $36 \pm 3 \cdot 7$ \\
\hline PGA $\ddagger$ & $57 \pm 9$ & $79 \pm 14$ & $3 \pm 0$ & $18 \pm 2$ & 0 & $2 \pm 0$ & $28 \pm 4 \cdot 6$ \\
\hline Xylan & $5 \pm 2$ & $12 \pm 3$ & $33 \pm 9$ & $7 \pm 1$ & 0 & $1 \pm 0$ & $34 \pm 4 \cdot 1$ \\
\hline CMCS & $2 \pm 0$ & $4 \pm 0$ & $8 \pm 1$ & $8 \pm 2$ & $1 \pm 0$ & $\overline{0}$ & $14 \pm 2$ \\
\hline Crystalline cellulose & $2 \pm 1$ & $2 \pm 0$ & $3 \pm 1$ & $12 \pm 2$ & $1 \pm 0$ & $1 \pm 0$ & $\mathrm{NM}$ \\
\hline Glucose & $2 \pm 0$ & $2 \pm 0$ & 0 & 0 & 0 & $1 \pm 0$ & $43 \pm 3 \cdot 4$ \\
\hline
\end{tabular}

*Enzyme type: pectinase (pectin); PG (PGA); xylanase (xylan); cellulase (CMC); Pr1 (Suc-Ala ${ }_{2}$-Pro-Phe-NA); Pr2 (Z-Phe-Val-Arg-NA). $\dagger \mathrm{NM}$, not measured

$\ddagger$ PGA, sodium polygalacturonate.

CMCS, CM-cellulose.

Table 3. Protease and polysaccharidase activities of extracellular preparations from $V$. lecanii strain 313 grown on a range of carbon sources for $4 \mathrm{~d}$

Cultures $(50 \mathrm{ml})$ were inoculated with $2 \times 10^{6}$ spores. Abbreviations are defined in the legend to Table 2 .

\begin{tabular}{|c|c|c|c|c|c|c|c|}
\hline \multirow{2}{*}{$\begin{array}{l}\text { Carbohydrate } \\
\text { growth substrate }\end{array}$} & \multicolumn{4}{|c|}{ Sugar released $\left(\mu \mathrm{g} \mathrm{ml}^{-1} \mathbf{h}^{-1}\right)$} & \multicolumn{2}{|c|}{$p \mathrm{NA}$ released $\left(\mathrm{nmol} \mathrm{ml} \mathbf{l}^{-1} \mathrm{~min}^{-1}\right)$} & \multirow{2}{*}{$\begin{array}{c}\text { Biomass } \\
\langle\mathrm{mg} \text { dry wt }\rangle\end{array}$} \\
\hline & Pectin & PGA & Xylan & $\mathrm{CMC}$ & $\begin{array}{c}\text { Suc-Ala }{ }_{2}^{-} \\
\text {Pro-Phe-NA }\end{array}$ & $\begin{array}{c}\text { Z-Phe-Val- } \\
\text { Arg-NA }\end{array}$ & \\
\hline Alfalfa cell walls & 0 & $35 \pm 7$ & 0 & 0 & $16 \pm 3$ & $12 \pm 2$ & NM \\
\hline M. sexta cuticle & 0 & $31 \pm 8$ & 0 & 0 & $83 \pm 7$ & $74 \pm 3$ & NM \\
\hline Pectin & 0 & $\overline{0}$ & 0 & 0 & $2 \pm 0$ & $5 \pm 1$ & $3 \pm 1$ \\
\hline PGA & 0 & $6 \pm 3$ & 0 & 0 & $16 \pm 3$ & $10 \pm 3$ & $14 \pm 2$ \\
\hline Xylan & 0 & 0 & 0 & 0 & 0 & $1 \pm 0$ & $4 \pm 0$ \\
\hline $\mathrm{CMC}$ & 0 & 0 & 0 & 0 & $5 \pm 1$ & $1 \pm 0$ & $2 \pm 0$ \\
\hline Crystalline cellulose & 0 & 0 & 0 & 0 & $5 \pm 1$ & $3 \pm 1$ & $\mathrm{NM}$ \\
\hline Glucose & 0 & 0 & 0 & 0 & $18 \pm 2$ & $9 \pm 2$ & $52 \pm 4 \cdot 3$ \\
\hline
\end{tabular}

Phe-AFC (Fig. 1a). Lower levels and a reduced complexity of bands were produced by other strains (Fig. 1a). However, basic and/or neutral bands were also produced by $V$. albo-atrum and $V$. dabliae The major trypsin-like $\operatorname{Pr} 2$ enzymes produced by Verticillium spp. detected with $\mathrm{Z}$-Val-Leu-Arg-AFC were very basic ( $\mathrm{pI}$ $>10$ ) and diffused into the region of the electrode (Fig. 1b). Additional acidic bands (pI ca 4.5) were also detected. The highest producer was $V$. albo-atrum.

The data from the IEF gels suggest that trypsin-like enzymes are the major proteases produced by plantpathogenic Verticillium spp. To confirm this, culture filtrates were assayed against a range of substrates previously used to detect subtilisins and trypsins in insect pathogens (St Leger et al., 1987b, c) (Table 4). V. lecanii and $V$. fungicola cleaved the subtilisin substrate Suc-Ala ${ }_{2}$-Pro-Phe-NA faster than Z-Phe-Val-Arg-NA and possessed no activity against Z-Val-Gly-Arg-NA or Z-Pro-Phe-Arg-NA, indicating that the trypsins of these species require specific substrate sequences. In contrast, the plant pathogens hydrolysed all three trypsin substrates and cleaved the most susceptible of these (Z-ValGly-Arg-NA) at least tenfold faster than Suc-Ala ${ }_{2}-$ ProPhe-NA (Table 4).

\section{Regulation of proteases}

The production of proteases by $V$. albo-atrum and $V$. lecanii was compared on potential protease substrates 
(a)

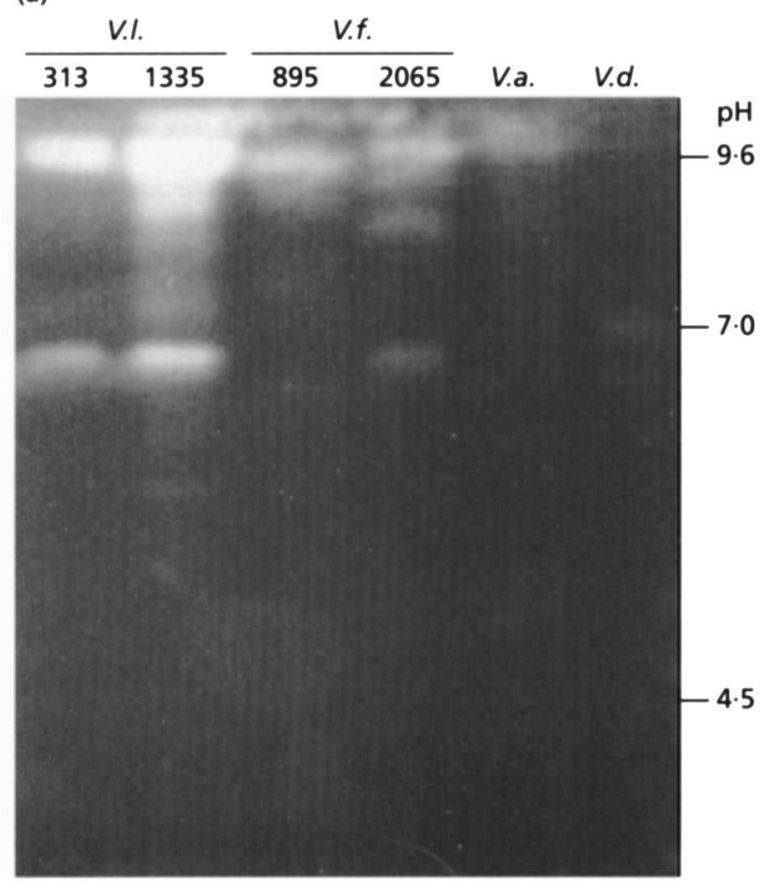

(b)

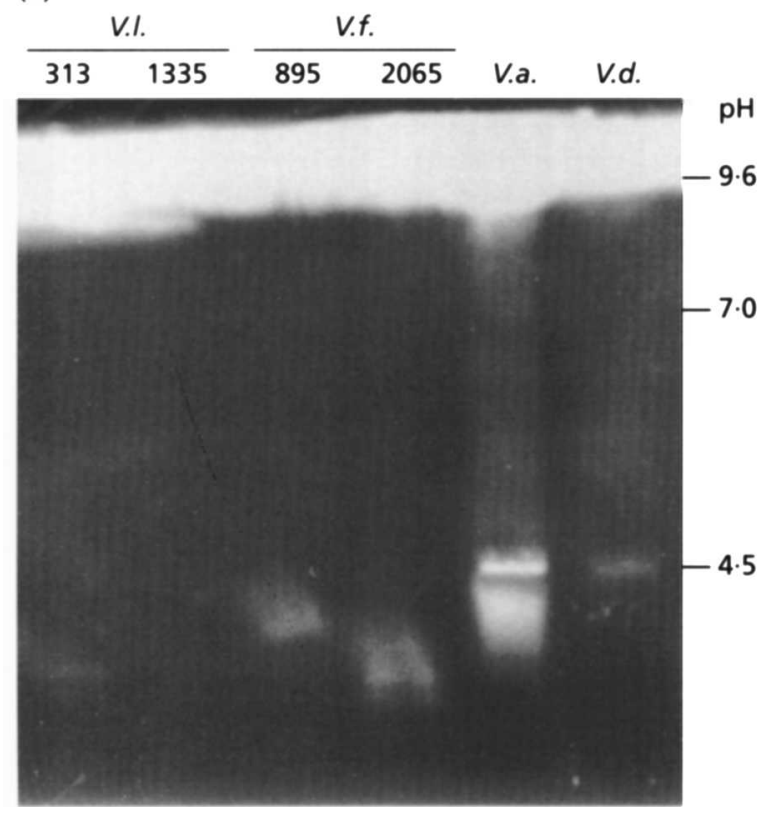

Fig. 1. Analytical (polyacrylamide) IEF ( $\mathrm{pH} 3-10)$ of proteinases produced by $V$. lecanii $(V$. l.) , $V$. fungicola $(V . f),$.$V . albo-atrum$ $(V$. a.) and $V$. dahliae ( $V$. d.) grown for $72 \mathrm{~h}$ in $1 \%$ collagen medium. Zymograms were prepared with EOMs containing (a) Suc-Ala ${ }_{2}$-Pro-Phe-AFC and (b) Z-Val-Leu-Arg-AFC for isoforms of subtilisin-like proteases ( $P r 1)$ and trypsin-like proteases ( $P r 2)$, respectively. The membrane/gel sandwiches were incubated at $37^{\circ} \mathrm{C}$ for $10 \mathrm{~min}$.

('Table 5). V. albo-atrum produced most $\operatorname{Pr} 1$ and $\operatorname{Pr} 2$ activities on medium supplemented with collagen. $M$. sexta cuticle was also a good inducer of proteases. Low levels of protease were produced in the presence of plant cell walls. A similar pattern of protease induction by protein substrates was observed with V. lecanii, except that the highest levels were produced on the cuticle substrate. Analysis of $V$. albo-atrum protease composition by gelatin SDS-PAGE revealed that two major isoforms were produced in each medium (Fig. 2a). Both isoforms had activity against the trypsin substrates Z-Val-Leu-Arg-AFC (Fig. 2b) and Z-Gly-Gly-Arg-AFC (Fig. 2c) but lacked activity against an EOM containing Suc-Ala ${ }_{2}$-Pro-Phe-NA (data not shown).

\section{Effect of inhibitors on protein degradation}

The relative contributions of $\operatorname{Pr} 1$ - and $\operatorname{Pr} 2$-type enzymes from $V$. lecanii and $V$. albo-atrum to degradation of hide protein azure and $M$. sexta cuticle were assessed with specific inhibitors for each enzyme. The $\operatorname{Pr} 1$ inhibitor Suc-Ala ${ }_{2}$-Pro-Phe- $\mathrm{CH}_{2} \mathrm{Cl}$ (St Leger et al., 1994) inhibited degradation of cuticle and hide protein azure by ca $90 \%$ in culture filtrates of $V$. lecanii containing both $\operatorname{Pr} 1$ and $\operatorname{Pr} 2$ (Table 6). The Pr2 inhibitor leupeptin (St Leger et al., 1996a) did not significantly inhibit protein degradation. In contrast, in culture filtrates of V. albo-atrum, Suc-Ala 2 -Pro-Phe- $\mathrm{CH}_{2} \mathrm{Cl}$ was more effective at inhibiting cuticle degradation $(66 \%)$ than leupeptin $(30 \%)$ but less effective at inhibiting degradation of hide protein azure $(44 \%$ vs $75 \%$ ).

\section{DISCUSSION}

The saprophytes, including Aspergillus spp., produced the broadest spectrum of protein and polysaccharidehydrolysing enzymes, which could be useful in the complete hydrolysis of complex living and non-living organic substrates and implies the greatest genetic and biochemical versatility. This versatility may not result from specific adaptation but rather reflect maintenance of the ability to exploit resources which temporarily become available. This is consistent with the 'alert' opportunistic saprophyte/pathogen life style of these fungi as exemplified by $A$. flavus which contains strains pathogenic to plants, insects and mammals (Cotty et al., 1990).

Aspergillus spp. generally have a broad host range but low virulence, and usually require weakened hosts for colonization (Raper \& Fennell, 1965). The other diseasecausing fungi included in this study are all facultative saprophytes (true pathogens that can survive outside their hosts) that have specific genetic interactions with their hosts. Most are highly virulent on only a limited number of species. To be successful, most plant and insect pathogens breach the outer integument of their hosts. It is likely that in the evolution towards pathogenicity, an ancestral saprophytic fungus needed first to gain attributes enabling it to live on numerous plant species before refining those traits and/or developing additional devices to increase virulence on individual host species (Knogge, 1996). Because the enzymes required to gain entry into plant hosts (various poly- 
Table 4. Extracellular proteases in 4-d-old culture filtrates from isolates of four Verticillium spp. grown in $1 \%(w / v)$ collagen

Cultures $(20 \mathrm{ml})$ were inoculated with $7 \times 10^{5}$ spores. Filtrates were assayed at $23^{\circ} \mathrm{C}$ in $10 \mathrm{mM}$

Tris $/ \mathrm{HCl}, \mathrm{pH} 8,4 \%(\mathrm{v} / \mathrm{v})$ dimethyl sulfoxide with $0.06 \mathrm{mM}$ substrate. Activities are expressed as a percentage of maximum activity. Absolute values $\left(\mathrm{nmol} \mathrm{min}{ }^{-1} \mathrm{ml}^{-1}\right)$ corresponding to $100 \%$ are given in parentheses at the bottom of each column.

\begin{tabular}{|c|c|c|c|c|c|c|c|}
\hline \multirow[t]{3}{*}{ Substrate } & \multicolumn{7}{|c|}{ Activity $(\%)$ secreted by isolate } \\
\hline & \multicolumn{2}{|c|}{ V. lecanii } & \multicolumn{2}{|c|}{$V \cdot$ fungicola } & \multicolumn{2}{|c|}{ V. albo-atrum } & \multirow[t]{2}{*}{ V. dahliae } \\
\hline & 313 & 1335 & 895 & 2065 & $13-1$ & $90-1$ & \\
\hline Subtilisin & & & & & & & \\
\hline $\begin{array}{l}\text { Suc-Ala }{ }_{2} \text {-Pro-Phe-NA } \\
\text { Trypsin }\end{array}$ & 100 & 100 & 100 & 100 & 9 & 7 & 5 \\
\hline Z-Phe-Val-Arg-NA & 54 & 65 & 36 & 72 & 83 & 86 & 67 \\
\hline Z-Val-Gly-Arg-NA & 0 & 0 & 0 & 0 & 100 & 100 & 100 \\
\hline Z-Pro-Phe-Arg-NA & $\begin{array}{r}0 \\
(95)\end{array}$ & $\begin{array}{c}0 \\
(210)\end{array}$ & $\begin{array}{r}0 \\
(64)\end{array}$ & $\begin{array}{c}0 \\
(101)\end{array}$ & $\begin{array}{c}12 \\
(216)\end{array}$ & $\begin{array}{c}17 \\
(291)\end{array}$ & $\begin{array}{r}8 \\
(54)\end{array}$ \\
\hline
\end{tabular}

Table 5. Effect of different media supplements on $\operatorname{Pr} 1$ (vs Suc-Ala 2 -Pro-Phe-NA) and Pr2 (vs Z-Phe-Val-Arg-NA) activities in culture filtrates of $V$. lecanii and $V$. albo-atrum

Mycelial inocula from Sabouraud dextrose cultures was incubated for $24 \mathrm{~h}$ in $\mathrm{MM}$ supplemented with the potential inducer at $1 \%(\mathrm{w} / \mathrm{v})$.

\begin{tabular}{|c|c|c|c|c|}
\hline \multirow[t]{2}{*}{ Supplement } & \multicolumn{2}{|c|}{ V. albo-atrum } & \multicolumn{2}{|c|}{ V. lecanii } \\
\hline & $\operatorname{Pr} 1$ & $\operatorname{Pr} 2$ & $\operatorname{Pr} 1$ & $\operatorname{Pr} 2$ \\
\hline MM & $0 \cdot 0$ & $11 \cdot 4 \pm 1 \cdot 8$ & $0 \cdot 1 \pm 0$ & $0 \cdot 0$ \\
\hline Collagen & $32 \cdot 5$ & $345 \cdot 0 \pm 27 \cdot 7$ & $83 \cdot 1 \pm 12$ & $55 \cdot 4 \pm 8 \cdot 0$ \\
\hline M. sexta cuticle & $16 \cdot 2 \pm 2 \cdot 3$ & $296 \cdot 7 \pm 35 \cdot 5$ & $143 \cdot 7 \pm 19$ & $37 \cdot 7 \pm 6 \cdot 4$ \\
\hline Elastin & $5 \cdot 3 \pm 0.7$ & $117 \cdot 6 \pm 2 \cdot 2$ & $26 \cdot 5 \pm 2 \cdot 3$ & $8 \cdot 2 \pm 1 \cdot 1$ \\
\hline Alfalfa cell walls & $1 \cdot 5 \pm 0.1$ & $100 \cdot 5 \pm 16 \cdot 5$ & $4 \cdot 0 \pm 0 \cdot 2$ & $6 \cdot 8 \pm 1$ \\
\hline
\end{tabular}

saccharidases) are also produced by saprophytes, they are unlikely to represent the tools specifically developed by fungi to implement pathogenicity (Knogge, 1996). This does not preclude adaptation of enzyme production to the specific needs of a pathogen on a particular host plant, as shown by the contrasting pattern of enzyme production by pathogens with dicotyledonous and monocotyledonous hosts that reflects a disparity between the primary wall structures of these hosts (Cooper et al., 1988). Overall, our results suggest that specialized pathogens isolated from either plant or insect hosts are less versatile than the opportunists and saprophytes, with patterns of enzyme production corresponding to the protein and carbohydrate contents of plant or insect integuments. That entomopathogenic strains of three species produce little or no polysaccharidase activity may indicate adaptation to an ecological niche where these enzymes are not required. It is of interest that $V$. lecanii produced cellulase activity on solid medium, but not in liquid culture, where low levels of PG activity were detected. Thus genes encoding these carbohydrases are still present in $V$. lecanii but they are not expressed in as wide a range of environmental conditions as compared to $V$. albo-atrum. This presumably reflects adaptation of the biosynthetic regulation of key enzymes to the specific needs of different Verticillium spp. on their particular hosts. Due to the redundancy of the encoding genes, gene disruption experiments have not produced evidence that plant cell-wall-degrading enzymes are required for pathogenicity (Mendgen $e t$ al., 1996). Likewise, several proteases and chitinases act synergistically during pathogen degradation of insect cuticle (St Leger et al., 1996a, b). It is therefore possible to rationalize differences between insect and plant pathogens assuming that depolymerases are one of the interactive phenomena in a complex multifactorial 
(a)

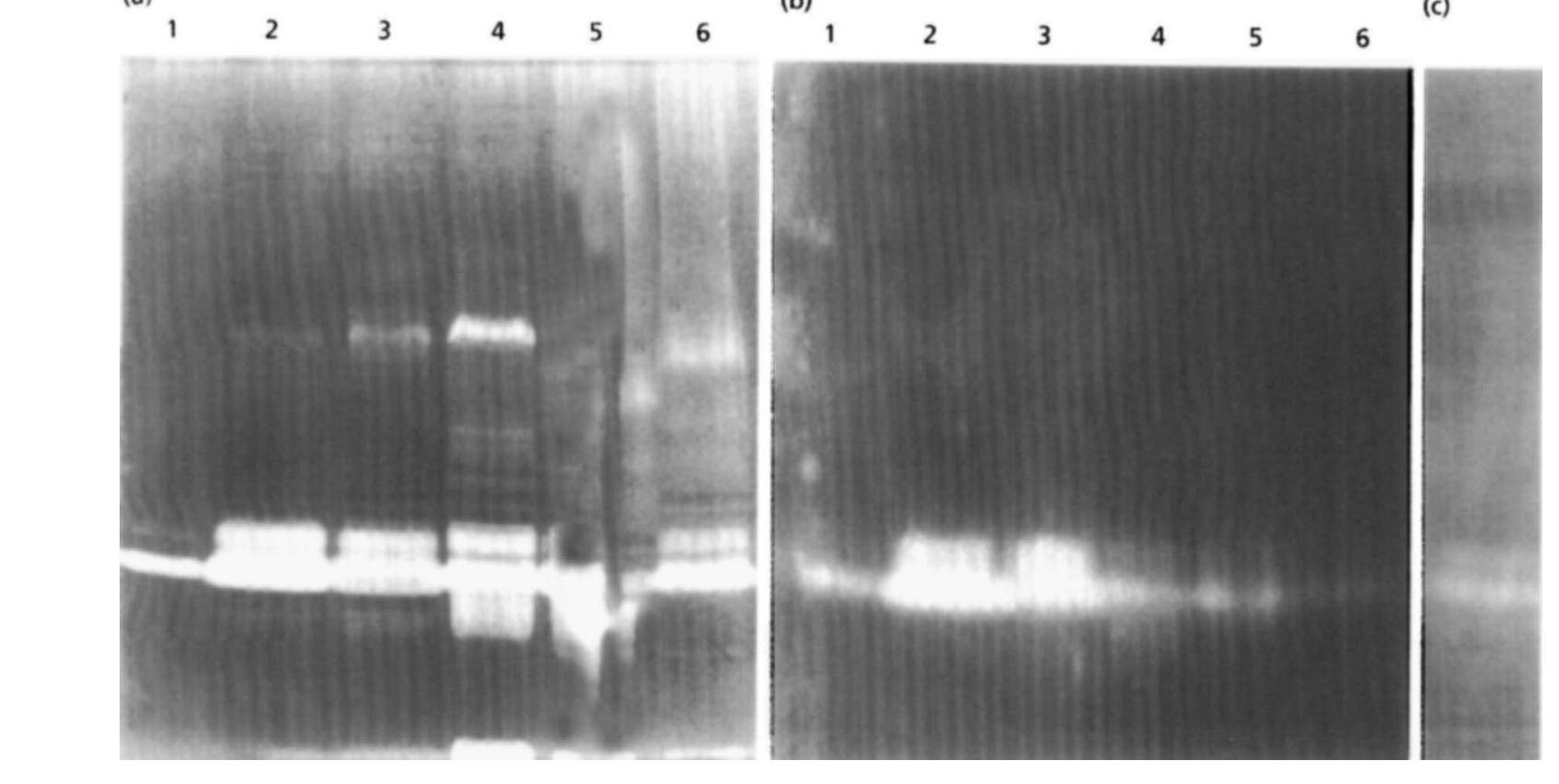

(b)

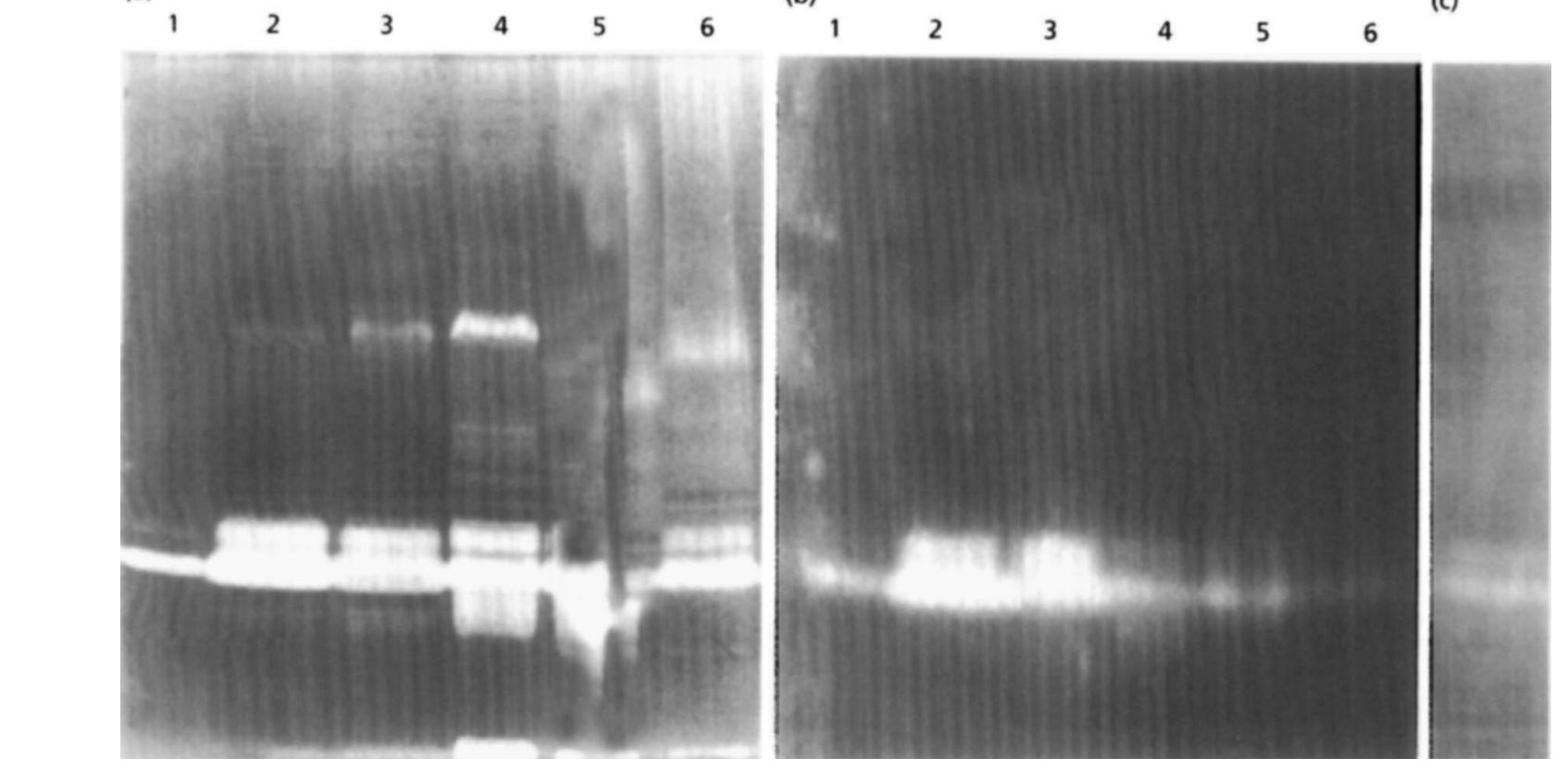

(c)

Fig. 2. SDS-PAGE analysis of proteinases produced by mycelial inocula of $V$. albo-atrum incubated for $24 \mathrm{~h}$ in basal medium (lanes 1) supplemented with collagen (2), M. sexta cuticle (3), elastin (4), alfalfa cell walls (5) and pectin (6). (a) Gelatin SDS-PAGE analysis. Cleared regions of the gel represent proteinase digestion of gelatin copolymerized with acrylamide. (b) Zymogram prepared with an EOM containing Z-Val-Leu-Arg-AFC. (c) Zymogram of lane 2 prepared with an EOM containing Z-Gly-Gly-Arg-AFC.

process enabling the pathogen to overcome host barriers. Consequently, pathogens of plants and animals differ by polygenic factors, that is, by genes of individually small effect that determine the extent of colonization of plants and insects. These enzymes considered separately are directly involved in, but are probably not essential for pathogenicity.

A large number of proteases are needed for complete digestion of the insect cuticle complex (St Leger, 1995). Nevertheless, the broad-spectrum subtilisin-like Pr1 protease is the major protein produced by $M$. anisopliae during infection processes and a comparison of the overall rates of hydrolysis suggests that Pr1 has a much greater ability than the trypsin-like $\operatorname{Pr} 2$ to degrade cuticle (St Leger et al., 1996a). In addition Pr1, unlike $\operatorname{Pr} 2$, is highly toxic to insects (St Leger et al., 1996c). Subtilisin-related proteases may therefore have a greater potential for pathogenicity to insects and possibly also for scavenging extracellular proteins, their most likely biological role in saprophytes (Gunkle \& Gassen, 1989). However, as there are no reports of trypsins being secreted by saprophytes, trypsin-related enzymes presumably possess a specific role in pathogenicity. In our previous study on the proteases of $V$. lecanii, we suggested that the very narrow specificities of their $\operatorname{Pr} 2$ enzymes, cleaving at the C-terminal of Phe-Val-Arg, may be required for selective extracellular proteolytic activation and inactivation processes (St Leger et al., 1987c). In contrast to pathogens with insect hosts, only low levels of subtilisins accumulated in cultures of $V$. albo-atrum and $V$. dabliae. Apparently during adaptation of Verticillium spp. to the plant wall the functions of a broad-spectrum protease were assumed by trypsins. The broader specificity of these enzymes as compared with the enzymes from entomopathogens is presumably responsible for their activity against hide protein azure and the leupeptin-sensitive hydrolysis of insect cuticle (Table 6). The profile of proteases produced by other plant-pathogenic fungi has not been thoroughly investigated. Subtilisin and trypsin activities were identified by gene cloning in Cochliobolus carbonum (Murphy \& Walton, 1996). Disruption of the trypsin gene reduced total proteolytic activity versus azocasein by up to $45 \%$, but pathogenicity was not affected, indicating that trypsin by itself is not required for pathogenicity. A trypsin from Fusarium oxysporum has also been characterized (Rypniewski et al., 1993). Like the plantpathogenic Verticillium spp., C. carbonum produced most total protease on collagen medium, a hydroxyproline-rich glycoprotein resembling structural proteins in plant cell walls (Murphy \& Walton, 1996). This suggests that trypsins are substrate-induced to degrade wall structural proteins. This may not be a pathogenic specialization, as collagen is also a good inducer of Aspergillus spp. proteases (St Leger, unpublished data). Insect cuticle stimulated protease production by both V.lecanii and V.albo-atrum, suggesting 
Table 6. Relative cuticle-degrading and anilidolytic activities of $\operatorname{Pr} 1$ and $\operatorname{Pr} 2$ in cultures of $V$. albo-atrum and $V$. lecanii grown on collagen for $2 \mathrm{~d}$

Culture filtrates were incubated with leupeptin $\left(25 \mu \mathrm{g} \mathrm{m}^{-1}\right)$ or Suc-Ala ${ }_{2}-\mathrm{Pro}-\mathrm{Phe}-\mathrm{CH}_{2} \mathrm{Cl}(0 \cdot 1 \mathrm{mM})$ for 30 min before assaying with $M$. sexta cuticle hide protein azure or specific anilide substrates for Pr1 (Suc-Ala ${ }_{2}$-Pro-Phe-NA) or Pr2 (Z-Phe-Val-Arg-NA). Controls contained autoclaved enzyme.

\begin{tabular}{|c|c|c|}
\hline \multirow[t]{2}{*}{ Substrates and inhibitors } & \multicolumn{2}{|c|}{ Relative activity of $\operatorname{Pr} 1$ and $\operatorname{Pr} 2$ produced by: } \\
\hline & V. albo-atrum & V. lecanii \\
\hline Suc-Ala ${ }_{2}$-Pro-Phe-NA* & $9 \pm 2$ & $95 \pm 7$ \\
\hline + Leupeptin & $9 \pm 3$ & $95 \pm 8$ \\
\hline+ Suc-Ala ${ }_{2}-$ Pro-Phe- $\mathrm{CH}_{2} \mathrm{Cl}$ & $1 \pm 0$ & $5 \pm 1$ \\
\hline Z-Phe-Val-Arg-NA* & $122 \pm 5$ & $68 \pm 5$ \\
\hline + Leupeptin & $12 \pm 0$ & $9 \pm 1$ \\
\hline+ Suc-Ala ${ }_{2}$-Pro-Phe- $\mathrm{CH}_{2} \mathrm{Cl}$ & $128 \pm 6$ & $73 \pm 8$ \\
\hline Hide protein azure $†$ & $14 \cdot 3 \pm 1 \cdot 1$ & $7 \cdot 5 \pm 0 \cdot 6$ \\
\hline + Leupeptin & $3 \cdot 5 \pm 0 \cdot 2$ & $7 \cdot 8 \pm 0 \cdot 7$ \\
\hline$+\mathrm{Suc}_{-\mathrm{Ala}}$-Pro-Phe- $\mathrm{CH}_{2} \mathrm{Cl}$ & $6 \cdot 3 \pm 0 \cdot 5$ & $0 \cdot 7 \pm 0 \cdot 1$ \\
\hline M. sexta cuticleł & $12 \pm 1 \cdot 3$ & $9 \cdot 5 \pm 0 \cdot 24$ \\
\hline + Leupeptin & $8 \cdot 4 \pm 0 \cdot 6$ & $8 \cdot 9 \pm 0 \cdot 46$ \\
\hline+ Suc-Ala ${ }_{2}$-Pro-Phe- $\mathrm{CH}_{2} \mathrm{Cl}$ & $5 \cdot 3 \pm 0 \cdot 3$ & $1 \cdot 3 \pm 0 \cdot 08$ \\
\hline
\end{tabular}

*Assays against $p \mathrm{NA}$ substrates were performed at $23^{\circ} \mathrm{C}$ in $10 \mathrm{mM} \mathrm{Tris} / \mathrm{HCl}, \mathrm{pH} 8,4 \%$ (v/v) dimethyl sulfoxide and $0 \cdot 6 \mathrm{mM}$ substrate. Activities were expressed as $\mu \mathrm{mol} \mathrm{NA} \mathrm{min}{ }^{-1} \mathrm{ml}^{-1}$.

† Activity against hide protein azure was determined at $23^{\circ} \mathrm{C}$ in $10 \mathrm{mM}$ Tris $/ \mathrm{HCl}, \mathrm{pH} 8$, containing $2.0 \mathrm{mg}$ cuticle $\mathrm{ml}^{-1}$. Following incubation for $15 \mathrm{~min}, A_{595}$ was measured. Activities were expressed as $\mu \mathrm{g}$ trypsin equivalents (St Leger et al., 1986a).

$\ddagger$ Activity against $M$. sexta cuticle was determined at $23^{\circ} \mathrm{C}$ in $10 \mathrm{mM} \mathrm{Tris} / \mathrm{HCl}, \mathrm{pH} 8$, containing $2.5 \mathrm{mg}$ cuticle $\mathrm{ml}^{-1}$. Following incubation for $1 \mathrm{~h}, A_{280}$ of trichloroacetic-acid-soluble products was measured. Activities were expressed as $\mu \mathrm{mol}$ tyrosine equivalents $\mathrm{min}^{-1} \mathrm{ml}^{-1}$ (St Leger et al., 1992).

that adaptation of Verticillium spp. to the insect cuticle did not require substantial changes in the regulatory controls of protease gene expression.

An interesting contrast to this strategy is provided by the extracellular metalloproteases of the obligate plant pathogen Uromyces viciae-fabae, which specifically degrade fibrous, hydroxyproline-rich proteins (Rauscher et al., 1995). These enzymes are regulated in a differentiation-specific manner, i.e. their synthesis requires fungal morphogenesis but not the presence of substrate (Rauscher et al., 1995). The refined specificity of these proteases, and their mode of regulation reflects a further degree of specialization achieved by obligate pathogens, as compared to facultative saprophytes such as Cochliobolus spp., Verticillium spp. and F. oxysporum.

\section{ACKNOWLEDGEMENTS}

This research was supported, in part, by grant 9602033 of the US Department of Agriculture and by a grant from the Park Foundation, Ithaca, NY, USA. We thank David Kalb and Richard Humber for generously providing us with cultures from the Department of Plant Pathology at Cornell University and the USDA Entomopathogenic Fungus Collection at Cornell University, respectively.

\section{REFERENCES}

Amici, G. G., Grandesso, A., Motolla, G., Virga, T., Teodori, T., Maresca, M. C. \& Bocci, C. (1994). Verticillium peritonitis in a patient on peritoneal dialysis. Am J Nephrol 14, 216-219.

Bowyer, P., Clarke, B. R., Lunness, P., Daniels, M. J. \& Osbourn, A. E. (1995). Host range of a plant pathogenic fungus determined by a saponin detoxifying enzyme. Science $\mathbf{2 6 7}, 371-374$.

Carpita, N. C. \& Gibeaut, D. M. (1993). Structural models of primary cell walls in flowering plants: consistency of molecular structure with the physical properties of the walls during growth. Plant J 3, 1-30.

Charnley, A. K. (1984). Physiological aspects of destructive pathogenesis in insects by fungi: a speculative overview. In Invertebrate-Microbial Interactions, pp. 229-270. Edited by J. M. Anderson, D. M. Rayner \& D. W. A. Walton. London: Cambridge University Press.

Cooke, R. C. \& Whipps, J. M. (1993). Ecophysiology of Fungi. Oxford: Blackwell Scientific Publications.

Cooper, R. M. \& Wood, R. K. S. (1975). Regulation of synthesis of cell wall degrading enzymes by Verticillium albo-atrum and Fusarium oxysporum F. sp. lycopersica. Physiol Plant Pathol 5, 135-156.

Cooper, R. M., Longman, D., Campbell, A., Henry, M. \& Lees, P. E. (1988). Enzymatic adaptation of cereal pathogens to the monocotyledonous primary wall. Physiol Mol Plant Pathol 32, $33-48$.

Cotty, P. J., Cleveland, T. E., Brown, R. L. \& Mellon, J. E. (1990). 
Variation in polygalacturonase production among Aspergillus flavus isolates. Appl Environ Microbiol 56, 3885-3887.

Durrands, P. K. \& Cooper, R. M. (1988). Development and analysis of pectic screening media for use in the detection of pectinase mutants. Appl Microbiol Biotechnol 28, 463-467.

Gunkle, F. A. \& Gassen, H. J. (1989). Proteinase K from Tritorachium album. Eur J Biochem 179, 185-194.

Hankin, L. \& Anagnostakis, S. L. (1975). The use of solid media for detection of enzyme production by fungi. Mycologia 67, 597-607.

Hensel, M. \& Holden, D. W. (1996). Molecular genetic approaches for the study of virulence in both pathogenic bacteria and fungi. Microbiology 142, 1049-1058.

Knogge, W. (1996). Fungal infection of plants. Plant Cell 8, 1711-1722.

Lewis, D. H. (1987). Evolutionary aspects of mutualistic associations between fungi and photosynthetic organisms. In Evolutionary Biology of the Fungi, pp. 161-178. Edited by A. D. M. Raynor, C. M. Brasier \& D. Moore. Cambridge: Cambridge University Press.

Lockwood, B. C., North, M. J., Scott, K. I., Bremner, A. F. \& Coombs, G. H. (1987). The use of a highly sensitive electrophoresis method to compare the proteinases of trichomonads. Mol Biochem Parasitol 24, 89-95.

Mendgen, K., Hahn, M. \& Deising, H. (1996). Morphogenesis and mechanisms of pathogenicity by plant pathogenic fungi. Annu Rev Phytopathol 34, 367-386.

Miller, G. L. (1959). Use of dinitrosalicylic acid reagent for determination of reducing sugars. Anal Chem 31, 426-428.

Murphy, C. A., Cameron, J. A., Huang, S. J. \& Vinopal, R. T. (1996). Fusarium polycaprolactone depolymerase is cutinase. Appl Environ Microbiol 62, 456-460.

Murphy, J. M. \& Walton, J.D. (1996). Three extracellular proteases from Cochliobolus carbonum: cloning and targeted disruption of ALP1. Mol Plant-Microbe Interact 9, 290-297.

Oliver, R. \& Osbourn, A. (1995). Molecular dissection of fungal phytopathogenicity. Microbiology 141, 1-9.

Raper, K. B. \& Fennell, D. I. (1965). The genus Aspergillus. Baltimore: Williams \& Wilkins.

Rauscher, M., Mendgen, K. \& Deising, H. (1995). Extracellular proteases of the rust fungus Uromyces viciae-fabae. Exp Mycol $19,26-34$.

Riou, C., Freyssinet, G. \& Fevre, M. (1991). Production of cell-walldegrading enzymes by the phytopathogenic fungus Sclerotinia sclerotiorum. Appl Environ Microbiol 57, 1478-1484.

Roberts, D. W. \& Humber, R. A. (1981). Entomogenous fungi. In The Biology of Conidial Fungi, vol. 2, pp. 201-236. Edited by G. T. Cole \& B. Kendrick. New York: Academic Press.

Rypniewski, W. R., Hastrup, S., Betzel, C., Dauter, M., Dauter, Z., Papendorf, G., Branner, S. \& Wilson, K. S. (1993). The sequence and X-ray structure of the trypsin from Fusarium oxysporum. Protein Eng 6, 341-348.

Schafer, W. (1994). Molecular mechanisms of fungal pathogenicity to plants. Annu Rev Phytopathol 32, 461-477.

Schreiter, G., Butt, T. M., Beckett, A., Vestergaard, S. \& Moritz, G. (1994). Invasion and development of Verticillium lecanii in the western flower thrip, Frankliniella occidentalis. Mycol Res 98 , 1025-1034.

Segers, R., Butt, T. M., Kerry, B. R. \& Peberdy, J. F. (1994). The nematophagous fungus Verticillium chlamydosporium produces a chymoelastase-like protease which hydrolyses host nematode proteins in situ. Microbiology 140, 2715-2723.

Smith, R. E. (1984). Identification of protease isoenzymes after analytical iso-electric focusing using fluorogenic substrates impregnated into cellulose membranes. J Histochem Cytochem 32, $1265-1274$.

St Leger, R. J. (1995). The role of cuticle-degrading proteases in fungal pathogens of insects. Can J Bot 73 suppl. 1, S1119-S1125.

St Leger, R. J. \& Bidochka, M. J. (1996). Insect-fungal interactions. In Invertebrate Immunology, pp. 441-478. Edited by K. Soderhall, G. Vasta \& S. Iwanaga. Fair Haven, NJ: SOS Publications.

St Leger, R. J., Cooper, R. M. \& Charnley, A. K. (1987a). Production of cuticle degrading enzymes by the entomopathogen Metarhizium anisopliae during infections of cuticle from Calliphora vomitaria and Manduca sexta. J Gen Microbiol 133, 1371-1382.

St Leger, R. J., Charnley, A. K. \& Cooper, R. M. (1987b). Characterization of cuticle-degrading proteases produced by the entomopathogen Metarbizium anisopliae. Arch Biochem Biophys 253, 221-232.

St Leger, R. J., Cooper, R. M. \& Charnley, A. K. (1987c). Distribution of chymoelastases and trypsin-like enzymes in five species of entomopathogenic deuteromycetes. Arch Biochem Biophys 258, 123-131.

St Leger, R. J., Bidochka, M. J. \& Roberts, D. W. (1994). Isoforms of the cuticle degrading $\operatorname{Pr} 1$ protease and production of a metalloproteinase by Metarhizium anisopliae. Arch Biochem Biophys 313, 1-7.

St Leger, R. J., Joshi, L., Bidochka, M. J., Rizzo, N. W. \& Roberts, D. (1996a). Biochemical characterization and ultrastructural localization of two extracellular trypsins produced by Metarhizium anisopliae in infected insect cuticles. Appl Environ Microbiol 62, 1257-1264.

St Leger, R. J., Joshi, L., Bidochka, M. J., Rizzo, N. W. \& Roberts, D. W. (1996b). Characterization and ultrastructural localization of chitinases from Metarhizium anisopliae, M. flavoviride and Beauveria bassiana during fungal invasion of host (Manduca sexta) cuticle. Appl Environ Microbiol 62, 907-912.

St Leger R. J., Joshi, L., Bidochka, M. J. \& Roberts, D. W. (1996c). Construction of an improved mycoinsecticide overexpressing a toxic protease. Proc Natl Acad Sci USA 93, 6349-6354.

Teather, R. M. \& Wood, P. J. (1982). Use of congo-red polysaccharide interactions in enumeration and characterization of cellulolytic bacteria from the bovine rumen. Appl Environ Microbiol 43, 777-780.

Walton, J. D. (1994). Deconstructing the cell wall. Plant Pbysiol 104, 1113-1118.

York, W. S., Darvill, A. G., McNeil, M., Stevenson, T.T. \& Albersheim, P. (1985). Isolation and characterization of plant cell walls and cell wall components. Methods Enzymol 118, 3-40.

Received 21 October 1996; revised 27 January 1997; accepted 2 February 1997. 